\title{
Correction to: Important Treatment Outcomes for Patients with Psoriatic Arthritis: A Multisite Qualitative Study
}

\author{
Emma Dures ${ }^{1,6} \cdot$ Sarah Hewlett $^{1} \cdot$ Jane Lord $^{2} \cdot$ Clive Bowen $^{3} \cdot$ Neil McHugh $^{4} \cdot$ For the PROMPT Study Group . \\ William Tillett $^{5}$
}

Published online: 23 March 2019

(c) The Author(s) 2019

\section{Correction to: Patient (2017) 10:455-462 https://doi.org/10.1007/s40271-017-0221-4}

The Open Access license, which previously read:

Open Access This article is distributed under the terms of the Creative Commons Attribution-NonCommercial 4.0International License (http://creativecommons.org/licenses/ by-nc/4.0/), which permits any noncommercial use, distribution, and reproduction in any medium, provided you give appropriate credit to the original author(s) and the source, provide a link to the Creative Commons license, and indicate if changes were made.

Should read:

Open Access This article is distributed under the terms of the Creative Commons Attribution 4.0 International License (http://creativecommons.org/licenses/by/4.0/), which permits unrestricted use, distribution, and reproduction in any medium, provided you give appropriate credit to the original author(s) and the source, provide a link to the Creative Commons license, and indicate if changes were made.

The original article has been corrected.

The original article can be found online at https://doi.org/10.1007/ s40271-017-0221-4.

Emma Dures

emma2.dures@uwe.ac.uk

University of the West of England, Bristol, UK

2 University Hospitals Bristol, Bristol, UK

3 The Psoriatic Arthritis Support Group (PsAZZ), Bath, UK

4 University of Bath, Bath, UK

5 Royal National Hospital for Rheumatic Diseases, Bath, UK

6 Academic Rheumatology, Bristol Royal Infirmary, Bristol BS2 8HW, UK
Open Access This article is distributed under the terms of the Creative Commons Attribution 4.0 International License (http://creat ivecommons.org/licenses/by/4.0/), which permits unrestricted use, distribution, and reproduction in any medium, provided you give appropriate credit to the original author(s) and the source, provide a link to Creative Commons license, and indicate if changes were made. 